\title{
HAHOMION NA TOLU
}

\section{Oleh: Rines Onixy Tampubolon}

(Pembimbing Tugas Akhir: Dr. Ni Nyoman Sudewi, S.S.T, M.Hum dan

Drs. Bambang Tri Atmadja, M.Sn)

Jurusan Tari, Fakultas Seni Pertunjukan, Institut Seni Indonesia Yogyakarta

\section{RINGKASAN}

Dalihan Natolu adalah pandangan hidup dalam masyarakat Batak yang memiliki nilai-nilai yang bersifat universal. Dalihan Natolu terbagi menjadi tiga kedudukan fungsional di dalam masyarakat Batak yaitu, Somba Marhulahula (hormat kepada keluarga dari pihak istri), Elek Marboru (mengayomi wanita), dan Manat Mardongan Tubu (bersikap sopan/hati-hati kepada teman semarga). Tiga kedudukan yang menjadi penyokong adat inilah yang disimbolisasikan ke dalam bentuk visual Dalihan Natolu (tungku berkaki tiga). Tungku yang memiliki tiga kaki, memiliki keseimbangan yang mutlak, karena tungku tersebut tidak dapat berdiri dan tidak dapat digunakan apabila salah satu kakinya rusak. Berdasarkan makna tersebut, leluhur suku Batak memilih tungku berkaki tiga sebagai falsafah hidup dalam tatanan kekerabatan antara sesama yang bersaudara atau satu marga dengan kelompok pemberi istri dan kelompok penerima istri. Segala kegiatan adat masyarakat Batak tidak dapat berjalan dan terlaksana apabila salah satu dari ketiga unsur tersebut tidak ada.

Dalam karya Hahomion Na Tolu, penggunaan tiga orang penari yang terdiri dari satu penari perempuan dan dua penari laki-laki dianalogikan sebagai gambaran konsep keseimbangan nilai tiga yang terkandung dalam Dalihan Natolu. Koreografi dalam garap tari kelompok ini memanfaatkan media gerak hasil pengembangan beberapa motif tari Tor-Tor Batak. Pengolahan motif ditekankan pada kualitas gerak tegas, kuat, dan perwujudan desain yang menunjukkan keseimbangan melalui gerak-gerak saling menyangga dan lifting. Busana dalam koreografi ini menggunakan bahan Ulos dan pilihan warna lebih pada warna merah, hitam dan putih, ketiganya merupakan warna yang digunakan dalam setiap kegiatan adat Batak. Musik tari adalah pengembangan pola-pola Gondang Uning-uningan Batak.

Kata kunci: Dalihan Natolu, keseimbangan, Batak 


\section{ABSTRACT}

Dalihan Natolu is considered as a view of life in Bataknese society's that has values which are universal. Dalihan Natolu is divided into three functional positions namely, Somba Marhulula (respect to the family of the wife), Elek Marboru (nursing women), and Manat Mardongan Tubu (be polite / careful to clan members). Those three positions that serve as proponent of the tradition are symbolized in the visual form of Dalihan Natolu (three-legged fireplace). The three-legged fireplace has an absolute balance, because the fireplace can not stand and can not be used when one of its legs is damaged. Based on that meaning, Bataknese ancestors chose a three-legged fireplace as a philosophy of life in a kinship arrangement between a brothers or a clan with a wife giver and wife receiver groups. All the activities of Bataknese's traditions can not be run and executed if one of the three elements are not there.

In the work of Hahomion $\mathrm{Na}$ Tolu, the use of three dancers consisting of one female dancer and two male dancers is analogous to the concept of the balance of three values contained in Dalihan Natolu. Choreography in the working on this group of dance is utilizing the motion media development of several motifs from Tor-Tor Bataknese Dance according to the stylist's design. The Motif processing is emphasized on the quality of motion firm, strong, and the embodiment of design that shows the balance through the motion of mutual support and lifting. Clothing in this choreography using Ulos material and more color choices on red, black and white, all three are the colors used in every Bataknese's tradition activities. The music for the dance is formatted live with patterns of bataknese's Gondang Uning-uningan's development.

Key words: Dalihan Natolu, Balance, Group of dance

\section{PENDAHULUAN}

Koreografi kelompok berjudul "Hahomion $\mathrm{Na}$ Tolu" bersumber dari pandangan hidup sosial dan budaya masyarakat Batak, Dalihan Natolu. Dalihan Natolu yang menjadi sumber penciptaan karya tari ini mencerminkan hubungan-hubungan kekerabatan darah (silsilah/garis keturunan) dan hubungan perkawinan yang mempertalikan satu kelompok. Dalam kehidupan masyarakat Batak, Dalihan Natolu sebagai pandangan hidup memiliki tiga kedudukan fungsional yaitu: (1) Somba Marhulahula (hormat kepada keluarga dari pihak istri, (2) Elek Marboru 
ISSN: 1858-3989

(mengayomi wanita), dan (3) Manat Mardongan Tubu (bersikap sopan/hati-hati kepada teman semarga). (Binsar Muller Siahaan, 2009:29)

Awal terbentuknya sistem kekerabatan Dalihan Natolu dilatarbelakangi oleh terjadinya masa kelabu Batak Toba. Hal ini dikemukakan oleh Binsar Muller Siahaan dalam buku Parrambuan Adat Batak Dalihan Natolu. (2009:23) Menurut Binsar Muller Siahaan pada masa itu pria Batak Toba mengalami kesulitan untuk mendapatkan pasangan hidup, dikarenakan pada masa ini menurut mitologinya, banyak wanita Batak Toba yang hilang begitu saja (diculik oleh sesuatu yang tidak tampak) dan menjalin hubungan dengan siluman. Hal ini mengakibatkan munculnya beberapa pemikiran dan tindakan seperti, seorang wanita ketika sudah ditinggalkan oleh suaminya adalah hak dari saudara laki-laki suaminya, terjadi perkawinan antara saudara, terjadi pertunangan di bawah umur bahkan masih di dalam kandungan sudah dijodohkan. Situasi dan kondisi seperti ini dialami orang Batak Toba selama tujuh generasi, dimulai dari masa pemerintahan Si Raja Batak pertama tahun 1364 hingga pemerintahan Raja Sisingamangaraja 1 (Raja Manghuntal generasi ketujuh Raja Batak) tahun 1550. Saat itu tidak ada aturan hidup yang harus dipatuhi maupun yang dipedomani. (Binsar Muller
Siahaan, 2009:26) Setiap orang berbuat menurut kehendaknya sendiri karena tidak ada aturan yang mengikat.

Pada masa pemerintahan Raja Sisingamangaraja I, berita tentang masa kelabu itu sampai kepada Raja Malim atau Raja Uti VII yang bermukim di Pulau Munsung Babi. Raja Malim menyarankan kepada Raja Sisingamangaraja I supaya mengundang para pemuka masyarakat Batak Toba untuk berkumpul dan bermusyawarah guna meletakkan aturan hidup masyarakat yang dapat memberikan kebaikan bagi seluruh keluarga keturunan si Raja Batak. Sesuai dengan anjuran tersebut, maka pada sekitar akhir abad ke-15 atau awal abad ke-16, untuk pertama kalinya, diadakanlah Loloan Bolon (sidang musyawarah) di Bakkara (tempat kembali berdirinya kerajaan Batak setelah mengalami kemunduran akibat perang). (Binsar Muller Siahaan, 2009:27) Dalam Loloan Bolon tersebut, ditetapkan sistem kekerabatan atau kekeluargaan dan diterapkan juga penggunaan atau pemakaian marga sebagai dasar pengelompokan masyarakat Batak Toba. Kelompok semarga disebut Dongan Tubu, kelompok pemberi isteri disebut Hula-hula, kelompok penerima isteri disebut Boru. Seiring dengan pengelompokkan tersebut, dijadikanlah tungku nan tiga atau Dalihan Natolu sebagai simbol yang menggambarkan prinsip kerjasama ketiga 
komponen masyarakat itu. (Binsar Muller Siahaan, 2009:27)

Aktualisasi masyarakat Batak Toba itu kemudian disebut Masyarakat Dalihan Natolu. Dalihan Natolu didirikan berdasarkan kesetaraan, duduk sama rendah, berdiri sama tinggi, dan bertanggung jawab sesuai dengan fungsi kelompoknya masing-masing. Setiap orang Batak secara kontekstual akan merasakan dan mengalami ketiga posisi tersebut sesuai dengan status sosial hingga sampai ke tahap berkeluarga. Ada saatnya menjadi Hula-hula atau Tondong, ada saatnya menempati posisi Dongan Tubu atau Sanina, dan ada saatnya menjadi Boru. Dengan Dalihan $\mathrm{Na}$ Tolu, adat Batak tidak memandang posisi seseorang berdasarkan pangkat, harta, atau jabatan. Sebagai contoh dalam sebuah acara adat, Boru yang memiliki jabatan sebagai Gubernur harus siap bekerja mencuci piring atau memasak untuk melayani hula-hula yang status sosialnya lebih rendah. Itulah realitas kehidupan orang Batak yang sesungguhnya. Lebih tepat dikatakan bahwa Dalihan Natolu merupakan sistem demokrasi orang Batak karena sesungguhnya mengandung nilai nilai yang universal dalam tiga kedudukan fungsional yaitu, Somba Marhula-hula (hormat kepada keluarga dari pihak istri), Elek Marboru (mengayomi wanita bermarga), Manat Mardongan Tubu (bersikap sopan dan hati-hati dengan teman semarga).
Tiga kedudukan tersebut dituangkan ke dalam istilah Dalihan Natolu atau tungku berkaki tiga, memiliki makna bahwa tungku yang memiliki tiga kaki harus memiliki keseimbangan yang mutlak, karena tungku tersebut tidak dapat berdiri dan tidak dapat digunakan apabila salah satu kakinya rusak. Berbeda halnya apabila tungku tersebut memiliki empat atau lima kaki, apabila salah satu kakinya rusak tungku tersebut masih bisa berdiri dan dapat digunakan. Berdasarkan makna tersebut, leluhur suku Batak memilih tungku berkaki tiga menjadi falsafah hidup dalam tatanan kekerabatan antara sesama yang bersaudara atau satu marga dengan Hula-hula dan Boru. Segala kegiatan adat Batak tidak dapat berjalan dan terlaksana apabila salah satu dari ketiga unsur tersebut tidak ada.

Binsar Muller Siahaan dalam buku Parrambuan Adat Batak Dalihan Natolu menyatakan bahwa, adat Dalihan Natolu adalah adatnya orang bermarga. (2009:28) Berdasarkan pernyataan ini, Binsar Muller Siahaan ingin menjelaskan bahwa setiap orang yang memiliki marga (garis keturunan Batak) merupakan masyarakat Dalihan Natolu, yang menjadikan Dalihan Natolu sebagai pandangan hidup.

Berkaitan dengan hal tersebut penata menghubungkan ke dalam diri penata sendiri yang memiliki garis keturunan Batak dan 
memiliki marga, sehingga penata juga dapat disebut sebagai masyarakat Dalihan Natolu.

Dalam memaknai Dalihan Natolu yang memiliki nilai tiga sebagai pandangan hidup, penata mencoba mengaitkan ke dalam kehidupan penata ketika merantau dan bertemu dengan orang Batak yang memiliki marga yang sama dengan penata. Rasa kebersaman, saling menghormati, dan tolong menolong muncul sangat kuat dan erat. Hal ini dapat dipersepsikan sebagai salah satu dari tiga nilai yang terkandung dalam konsep Dalihan Natolu yaitu Manat Mardongan Tubu. Pengalaman hidup ini yang menjadi salah satu bukti yang menyadarkan penata bahwa Dalihan Natolu memiliki makna dan arti penting yang begitu kuat bagi masyarakat Batak. Sebagai generasi muda yang nantinya juga akan merasakan menjadi Hula-hula, Boru, dan Dongan Tubu, menjadikan karya ini sebagai wadah untuk menelaah dan memahami lebih dalam tentang konsep Dalihan Natolu. Diharapkan hal ini menjadi pemicu bagi teman-teman masyarakat Batak, yang nantinya mengalami hal yang sama, akan mampu memaknai dan menyadari arti penting dari konsep nilai tiga dalam Dalihan Natolu.

\section{PEMBAHASAN}

\section{A. Kerangka Dasar Pemikiran}

Karya ini mengkomunikasikan gagasan tentang Dalihan Natolu yang dipahami memiliki nilai tiga yaitu tiga kedudukan fugsional dalam konsep keseimbangan, yang ditujukan untuk laki-laki dan perempuan. Berkaitan dengan hal ini maka ada beberapa aspek tari yang diharapkan dapat mendukung penyampaiannya dalam sebuah karya tari. Adapun aspek-aspek tersebut mengarahkan ditetapkannya beberapa hal yaitu: 1) jumlah tiga penari, dua laki-laki dan satu perempuan dalam pengolahan gerak dengan formasi saling menyangga satu dengan yang lainnya. 2) Motif gerak yang berpijak pada Tor-tor Sombasomba, Tor-tor Olop-olop, Tor-tor Mangaliat, Tor-tor Mula-mula karena motif gerak ini selalu digunakan oleh ketiga penyokong adat yang terdapat dalam nilai Dalihan Natolu. 3) Properti Tandok (tempat beras yang dijunjung di atas kepala) dihadirkan dalam koreografi ini dengan tujuan untuk menyampaikan makna yang terkandung dalam Dalihan Natolu yaitu tentang kesetaraan terhadap beban yang ditanggung bersama untuk menjunjung adat, dan kebersamaan. 4) Menggunakan musik dengan mengeksplorasi instrumen musik Batak. 5) Busana penari menggunakan bahan Ulos yang didominasi warna putih, merah dan hitam, serta dibuat menjadi tiga design bentuk untuk menonjolkan sisi visual dari tiga kedudukan fungsional.

\section{B. Konsep Dasar Tari}

\section{Rangsang Tari}


Dalihan Natolu dijadikan sumber inspirasi dalam berkarya didasari oleh garis keturunan Batak yang ada dalam diri penata. Dalihan Natolu yang menjadi pandangan hidup masyarakat Batak, dipahami lebih dalam dengan penulusuran data yang melingkupi objek itu sendiri. Proses pencarian data tersebut menghasilkan berbagai macam pemahaman seperti konsep nilai tiga, tiga kedudukan fungsional, dan nilai keseimbangan. Pemahaman ini direfleksikan ke dalam pengalaman hidup penata. Hal ini yang mendorong untuk lebih memaknai nilai penting yang ada di dalam Dalihan Natolu, dan menuangkannya ke dalam sebuah karya. Gagasan yang dipetik dari objek Dalihan Natolu dan dijadikan landasan berkarya menegaskan bahwa rangsang yang digunakan dalam karya ini adalah rangsang gagasan, Jacqueline Smith (1976) dalam buku Dance Composition A Practical Guide For Teachers diterjemahkan oleh Ben Suharto (1985) Komposisi Tari, Sebuah Petunjuk Praktis Bagi Guru mengatakan bahwa gerak dirangsang dan dibentuk dengan intensi untuk menyampaikan gagasan atau untuk menggelarkan cerita. (Jacqueline Smith diterjemahkan oleh Ben Suharto, 1985:23) Karya ini juga menggunakan rangsang visual, yaitu penggunaan properti Tandok, terinspirasi dari wujud tungku berkaki tiga (Dalihan Natolu).

2. Tema Tari

Tema atau permasalahan pokok yang disampaikan dalam karya ini yaitu tentang konsep nilai keseimbangan tiga kedudukan fungsional Dalihan Natolu dalam menjunjung adat dan tradisi masyarakat Batak. Tiga kedudukan fungsional dalam Dalihan Natolu yaitu Somba Marhula-hula, Elek Marboru, dan Manat Mardongan Tubu. Ketiganya saling berhubungan, berperan secara seimbang menuju satu tujuan yaitu menjunjung adat dan budaya Batak.

3. Judul Tari

Dalihan Natolu merupakan objek yang dijadikan sebagai sumber ide penciptaan karya. Hal ini, memberikan gagasan untuk memilih judul "Hahomion $\mathrm{Na}$ Tolu". Hahomion $\mathrm{Na}$ Tolu dalam bahasa Batak jika diartikan ke dalam bahasa Indonesia memiliki arti sebagai berikut. Hahomion berarti "memahami makna secara mendalam", sedangkan na tolu berarti "yang tiga". Apabila digabungkan, Hahomion $\mathrm{Na}$ Tolu memiliki arti memahami makna yang tiga secara mendalam. Judul ini sangat sesuai dengan isi atau esensi karya yaitu, mengkomunikasikan makna dan nilai-nilai simbolis yang terkandung di dalam Dalihan Natolu. Konsep nilai tiga ini divisualisasikan melalui kehadiran tiga penari dalam garap tari kelompok. 


\section{Bentuk dan Cara Ungkap}

Koreografi berjudul "Hahomion $\mathrm{Na}$ Tolu" ini menggunakan bentuk koreografi kelompok dengan jumlah tiga orang penari, satu putri dan dua putra. Penggunaan tiga penari dalam karya ini dipilih berdasarkan nilai tiga yang terdapat di dalam Dalihan Natolu. Nilai tiga dalam konsep keseimbangan berkaitan dengan fungsinya maka dipilih penari putra dan putri, karena tiga kedudukan fungsional dalam Dalihan Natolu ada yang ditujukan untuk lakilaki dan perempuan. Nilai tiga dalam konsep keseimbangan diekspresikan dalam gerak dan formasi yang terbentuk akibat penari yang saling menyangga antara satu dengan yang lain. Dengan adanya pemilihan tiga penari, satu putri dan dua putra, dalam penyampaian tiga kedudukan fungsional, serta penyampaian konsep keseimbangan melalui gerak dan formasi penari sudah dapat dipastikan bahwa, karya ini menggunakan bentuk ungkap atau tipe tari dramatik dengan mode penyajian atau cara ungkap simbolik. Sama halnya dengan yang diungkapkan oleh Jacqueline Smith dalam buku Dance Composition A Practical Guide For Teachers diterjemahkan oleh Ben Suharto (1985) Komposisi Tari, Sebuah Petunjuk Praktis Bagi Guru bahwa tipe dramatik akan memusatkan perhatian pada kejadian atau suasana yang tidak menggelarkan ceritera. (Jacqueline Smith diterjemahkan oleh Ben Suharto, 1985:27)
Sedangkan mode penyajian simbolis ialah memeras intisari atau karakteristik umum dan menambah gambaran lain menjadi aksi atau tekanan dinamis. (Jacqueline Smith diterjemahkan oleh Ben Suharto, 1985:29) Dalam menyaksikan pertunjukan karya ini, penonton diberi 'ruang' untuk menginterpretasikan secara bebas.

\section{Konsep Garap Tari}

1. Gerak

Gerak yang akan diolah dalam koreografi ini berpijak pada gerak-gerak tari tradisi Batak seperti Tor-tor Mula-mula, Tor-tor Somba, Tor-tor Mangaliat, Tor-tor Sipitu Cawan dan Tor-tor Olop-olop. Kelima tarian ini merupakan tarian yang selalu digunakan oleh ketiga penyokong adat dalam setiap acara adat dengan diiringi musik Gondang Uninguningan Batak. Sebagai contoh, Tor-tor Somba-somba selalu dihaturkan kepada Hulahula dengan arti bahwa Hula-hula tersebut harus dihormati sesuai dengan nilai yang ada di dalam Dalihan Natolu. Dari tarian tersebut dipilih motif tertentu diantaranya motif somba (menyembah), mangolop, berjalan ditempat, jalan berbaris, menadahkan tangan dan manghunti (menjunjung sesuatu diatas kepala) sebagai materi awal koreografi ini. Berkaitan dengan nilai tiga dalam konsep keseimbangan, dalam karya ini yang diekspresikan dengan gerak dan formasi yang terbentuk akibat penari saling menyangga, dapat dikelompokkan atau 
diidentifikasi ke dalam gerak-gerak akrobatik. Koreografi ini juga mengolah gerak dengan menggunakan properti Tandok (tempat beras yang dijunjung di atas kepala) untuk menyampaikan makna kesetaraan terhadap beban yang ditanggung bersama dalam menjunjung adat, dan kebersamaan. Pola lantai yang digunakan dalam koreografi ini banyak mengolah pola lantai segitiga yang menggambarkan tiga posisi kedudukan fungsional tersebut.

\section{Penari}

Penari dalam koreografi ini berjumlah tiga orang, dua orang laki-laki (salah satunya adalah penata sendiri) dan satu orang perempuan. Konsep tiga penari berdasarkan konsep nilai tiga yang ada pada Dalihan Natolu. Penggunaan penari laki-laki dan perempuan juga berkaitan dengan konsep keseimbangan pada tiga kedudukan fungsional yang ada dalam Dalihan Natolu yaitu Somba Marhula-hula (ditujukan untuk laki-laki bermarga), Manat Mardongan Tubu (ditujuan untuk laki-laki bermarga) dan Elek Marboru (ditujukan untuk perempuan bermarga). Untuk kelancaran proses dan keberhasilan sebuah koreografi kelompok, maka kualifikasi penari perlu dipertimbangkan. Ditetapkan kualifikasi penari laki-laki yaitu yang memiliki postur sama dengan penata dan kemampuan tubuh yang bisa mengikuti ketubuhan penata baik dari segi teknik dan bentuk. Sedangkan kualifikasi satu penari perempuan yaitu harus memiliki teknik, stamina dan penjiwaan yang kuat, karena harus bersanding dengan dua penari laki-laki. Hal ini didasari dari konsep gerak yang banyak menggunakan stamina yang besar dan teknik mengangkat (lifting) oleh penari dengan formasi yang saling tumpang tindih atau saling. Kualifikasi lain yang dibutuhkan dalam karya ini adalah stamina penari yang prima, karena berkaitan dengan penambahan durasi dan teknik gerak akrobatik yang muncul akibat formasi tumpang tindih dalam konsep gerak.

3. Musik Tari

Musik tari yang akan digunakan adalah jenis musik tradisi Batak dengan instrumen musik seperti, Tagading, Sarune, Ogung, dan Suling. Instrumen-instrumen ini dieksplorasi berdasarkan pola Gondang Uning-uningan Batak yang dikembangkan. Hal ini bertujuan untuk menguatkan rasa dan spirit Batak dalam karya ini. Karya ini juga menggunakan instrumen musik Barat seperti Simbal, Drum, Bass, dan Organ sebagai pendukung dalam membangun suasana-suasana pada setiap adegan yang tidak bisa dimunculkan dari instrumen musik Batak. Berkaitan dengan tujuan menyampaikan konsep nilai tiga dalam karya ini, maka dicoba menggunakan vokal yang berisikan petuah atau nasehat tentang nilai dan makna Dalihan Natolu di dalam kehidupan masyarakat Batak. 


\section{Rias dan Busana}

Busana dalam karya ini menggunakan bahan Ulos (bahan ciri khas suku Batak) yang didominasi warna putih, merah dan hitam. Ulos tersebut akan didesain menjadi tiga bentuk untuk menonjolkan sisi visual dari setiap kedudukan fungsional, sehingga ada sedikit perbedaan antara penari yang satu dengan yang lain. Busana yang akan dikenakan didesain melekat pada tubuh sehingga tidak mengganggu penari dalam melakukan gerak akrobatik sesuai dengan konsep gerak yang dijelaskan sebelumnya. Warna merah, putih, dan hitam dipilih karena ketiganya merupakan warna khas yang selalu muncul dalam setiap kegiatan adat masyarakat Batak.

\section{Pemanggungan}

Tempat pementasan karya ini adalah proscenium stage Jurusan Tari Institut Seni Indonesia Yogyakarta. Pemilihan panggung ini mempertimbangkan bahwa karya ini merupakan karya Tugas Akhir sebagai syarat kelulusan di Program Studi S1 Seni Tari, sehingga pelaksanaannyapun akan dilaksanakan di Jurusan Tari Institut Seni Indonesia Yogyakarta. Panggung yang sudah disediakan untuk pementasan karya ini, dimanfaatkan sesuai dengan perspektif proscenium stage yang seharusnya, tanpa menambahkan setting atau batasan-batasan tertentu.

\section{Realisasi Karya}

1. Urutan Adegan

Karya tari yang berjudul "Hahomion $\mathrm{Na}$ Tolu" dibagi menjadi lima adegan atau segmen, berikut pembagian dan penjelasannya:

a) Adegan Pertama

Adegan pertama (introduksi) dalam karya yang berjudul "Hahomion $\mathrm{Na}$ Tolu" mempresentasikan tiga kedudukan fungsional yang terdapat dalam makna dan bentuk visual dari Dalihan Natolu (tungku berkaki tiga) yang kokoh dan kuat. Adegan pertama ini diawali dengan pemainan musik Gondang Mula-mula. Gondang Mula-mula merupakan jenis musik Batak yang selalu dimainkan dalam mengawali setiap kegiatan adat. Gondang Mula-mula dimaknai sebagai persiapan diri dan permohonan kepada Sang Pencipta agar apa yang dilaksanakan berjalan dengan lancar. Hal ini yang mendasari dihadirkan Gondang Mula-mula dibagian awal karya, karena penata tari memiliki harapan kelancaran dalam pementasan karya.

Hadirnya tiga orang penari, dua laki-laki dan satu perempuan dengan posisi rendah pada tiga titik yang membentuk segitiga, diibaratkan sebagai bentuk tiga kaki pada Dalihan Natolu (tungku berkaki tiga). Pada bagian ini gerak penari diawali dengan gerak Somba-somba (menyembah) yang memiliki arti ketiga kedudukan fungsional ini menghormati dan 
memulia Sang Pencipta. Musik iringan tari juga memberikan banyak penekanan pada setiap gerak penari dengan menggunakan instrumen perkusi, sehingga gerakan penari tampak lebih tegas dan kuat. Adegan introduksi ini diakhiri dengan fokus on tri point penari yang berjauhan dengan posisi berdiri dan diam dengan pola segitiga besar.

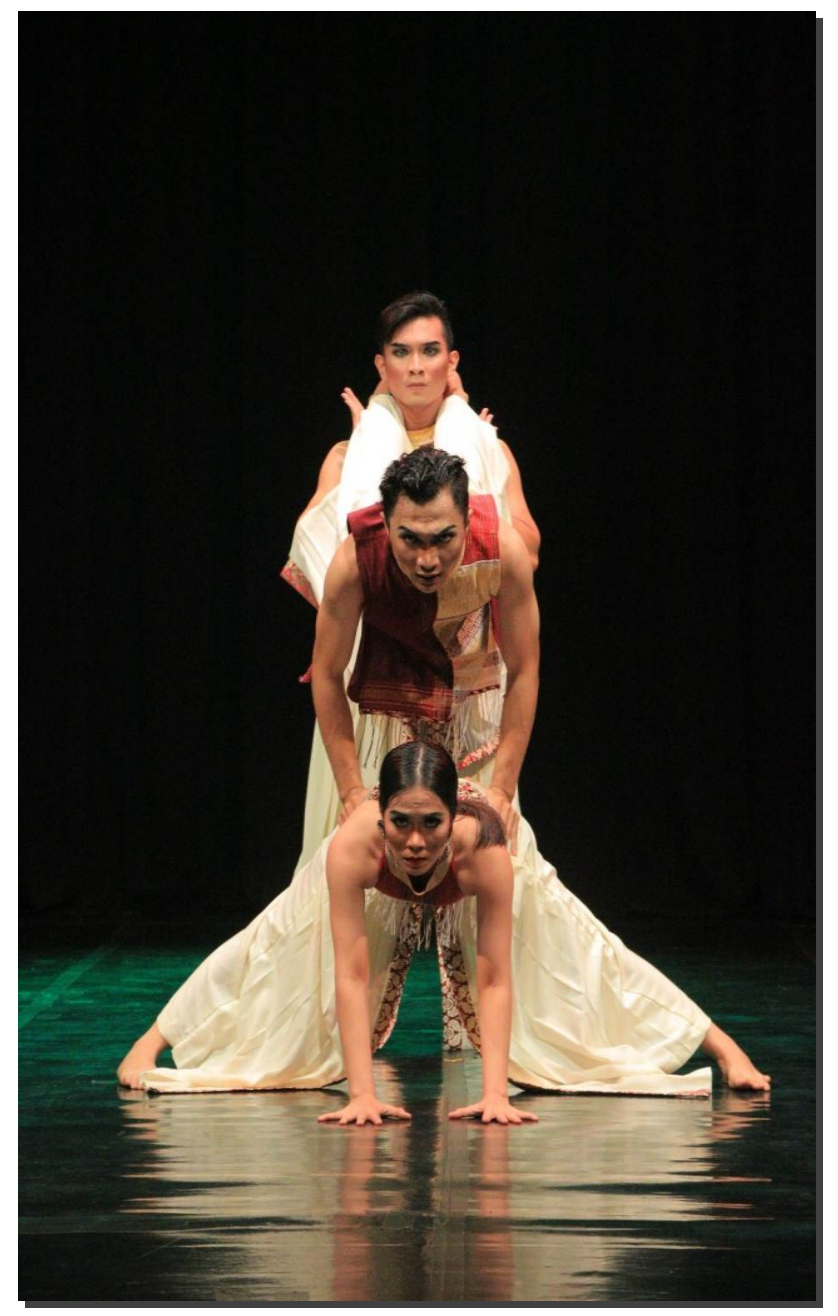

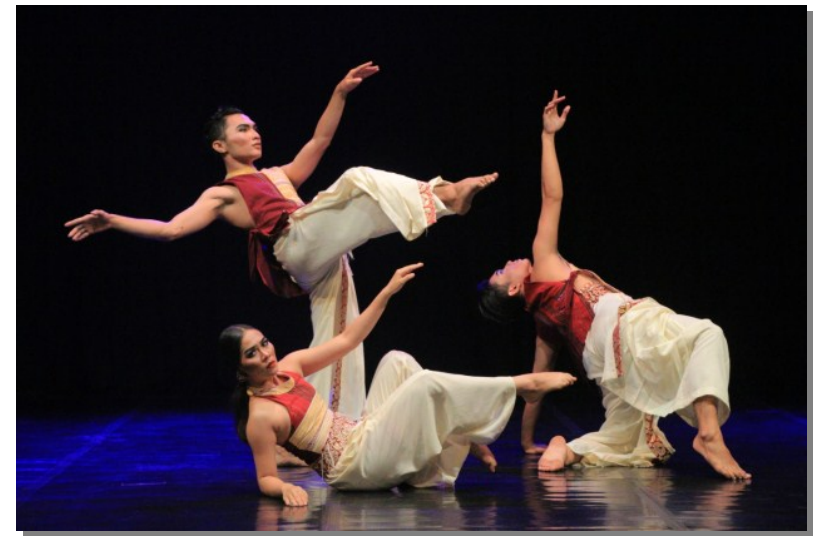

b) Adegan Kedua

Setelah adegan pertama atau introduksi selesai, lalu dilanjutkan menuju adegan kedua yang ditandai dengan perubahan musik keras menjadi musik yang lebih hening. Adegan kedua ini penata mencoba memaparkan satu persatu kedudukan fungsional yang terdapat pada makna Dalihan Natolu yang terdiri dari Somba Marhula hula, Elek Marboru dan Manat Mardongan Tubu. Setiap penari secara bergantian melakukan gerakan yang memiliki motivasi yang berbeda, sehingga dapat menyampaikan perbedaan dari setiap kedudukan tersebut. Gerak yang dilakukan penari secara bergantian untuk menonjolkan masing-masing kedudukan fungsional tersebut tidak semata-mata bergerak sendiri tanpa adanya hubungan antara penari yang satu dengan yang lain. Pada bagian ini gerak bergantian dalam menjabarkan setiap kedudukan fungsional yang menjadi fokus, harus memiliki hubung kait dengan penari lainnya. Salah satunya dalam mempresentasikan dan menonjolkan 
kedudukan fungsional Somba Marhula-hula (yang diperuntukkan pada laki-laki), satu penari laki-laki dengan posisi high level dengan gerak mamasu-masu (memberkhati) dan dua penari lainnya laki-laki dan perempuan berada pada posisi low level dengan melakukan gerakan somba-somba (menyembah).

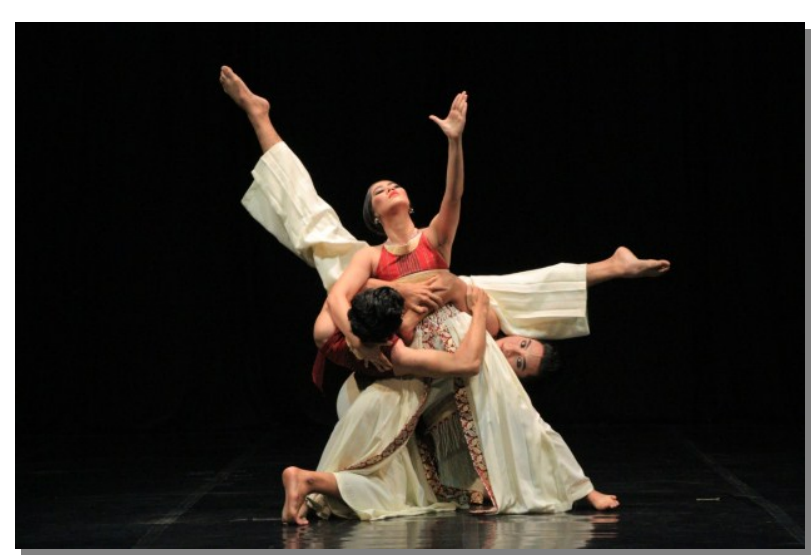

\section{c) Adegan Ketiga}

Adegan ketiga dalam karya yang berjudul "Hahomion Na Tolu" menyatakan hubungan dan keterkaitan antar ketiga kedudukan tersebut, yang dimana saling ketergantungan dan membutuhkan antar satu dengan yang lain, yang apabila salah satunya tidak ada maka setiap kegiatan adat tidak dapat berjalan. Pada adegan ketiga ini penata ingin menciptakan koreografi yang dapat menyampaikan sebuah bentuk kerjasama atau gotong royong yang berkaitan dengan hubungan antara ketiga kedudukan fungsional tersebut dengan menggunakan banyak teknik lifting (mengangkat) antara penari yang satu dengan yang lain, pola gerak berpindah (locomotor movement) baik berjalan ataupun berlari, dan gerak saling mengisi ruang antara penari yang satu dengan yang lain. Teknik gerak dan pola berpindah seperti ini digunakan penata untuk mewujudkan kerjasama atau gotong royong pada adegan ini, dikarenakan ketika penari melakukan lifting (teknik mengangkat) kepada penari yang lain secara langsung setiap penari harus memiliki tingkat kerjasama yang tinggi, yang apabila kerjasama itu tidak berhasil maka kemungkinan salah satu penari akan mengalami kecelakaan atau cidera. Pada adegan ketiga ini, musik iringan yang disajikan banyak menggunakan instrumen tiup Suling Batak. Hal ini bertujuan untuk membawa penari dan penoton merasakan suasana Bona Pasogit (kampung halaman).

d) Adegan Keempat

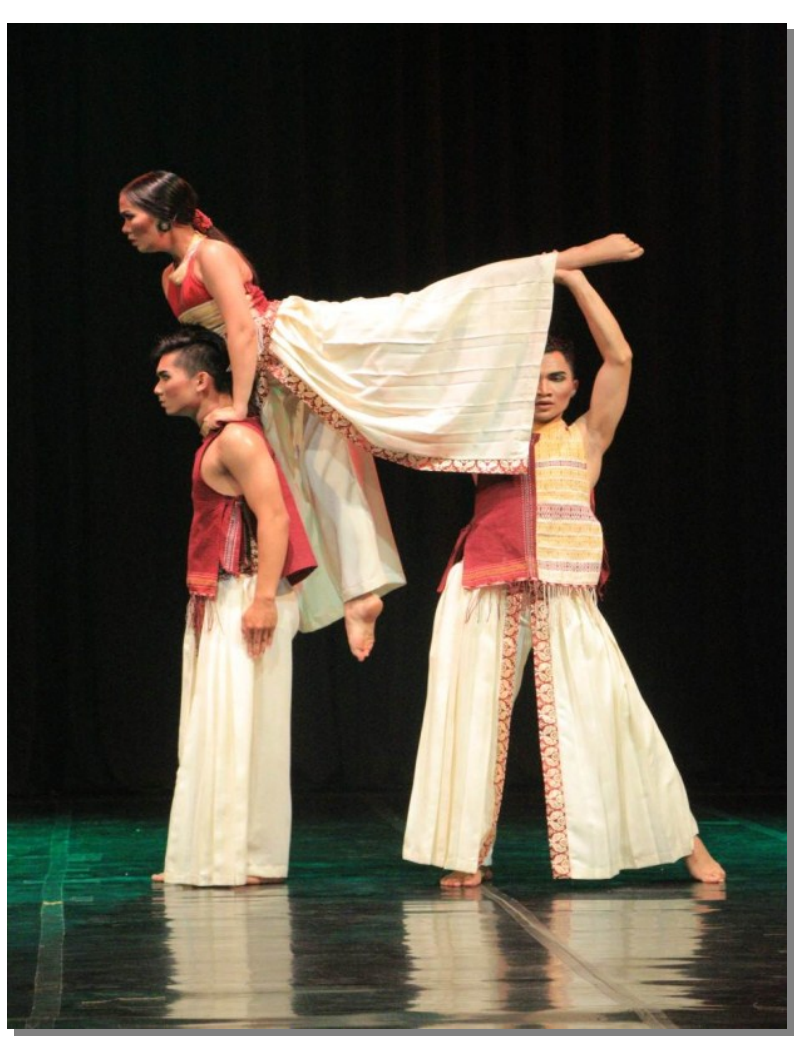


Adegan keempat ini menggambarkan beban tanggungjawab yang dimiliki oleh setiap masyarakat batak yang merupakan masyarakat Dalihan Natolu, yang dimana masyarakat batak memiliki tujuan yang sama dan beban untuk menjunjung tinggi adat dan tradisi Batak. Begitu pula dalam penerapan tiga kedudukan fungsioal tersebut, ketika salah satunya memiliki beban, maka beban itu adalah beban ketiganya. Untuk mewujudkan hal tersebut pada adegan keempat ini penata mengolah gerak berpindah (locomotor movement), yang mana setiap penari berpindah menuju posisi penari lainnya hingga semua penari merasakan setiap posisi yang dilalui oleh penari lainnya. Hal ini bertujuan untuk memaparkan bahwa setiap beban ataupun suatu hal yang dirasakan oleh tiga kedudukan fungsional itu harus dirasakan dan menjadi tanggungjawab yang lainnya pula. Adegan keempat diawali dengan pola lantai segitiga besar, yang mana ketiga penari akan bergerak menuju kedalam dan membuat pola lantai segitiga kecil di dead center. Berdasarkan pola lantai segitiga inilah penari akan berpindah tempat menuju posisi penari lain dengan arah berpindah lingkaran (cyrcle).

Musik iringan yang mengiri tari pada bagian keempat memiliki tempo cepat dan didominasi oleh instrumen perkusi yang memberikan suasana keceriaan dan semangat. Gerak yang disajikanpun banyak menggunakan gerakan yang memiliki keruangan yang luas dan banyak menggunakan teknik melompat. Hal ini bertujuan untuk menyampaikan beban dan tanggungjawab yang dimiliki bersama bukan merupakan suatu masalah, melainkan sebuah cara untuk saling bersyukur atas apa yang dimiliki. Pada bagian keempat ada poses pengambilan properti yaitu Tandok oleh penari perempuan. Tandok merupakan sebuah wadah untuk menempatkan beras yang dijunjung di atas kepala. Sehingga, penari harus memiliki keseimbangan yang tinggi untuk menjunjung properti ini agar tidak jatuh, karena properti ini memiliki ukuruan yang besar dan beban yang cukup berat. Proses pengambilan tandok oleh penari perempuan dilakukan dibelakang backdrop yang ditutupi oleh dua penari lakilaki didepannya. Lalu dilanjutkan membentuk formasi mengangkat salah satu penari laki-laki dibahu penari laki-laki satunya. Pada akhir bagian keempat ini penari perempuan menjunjung Tandok di atas kepala dan kedua penari laki-laki berpindah tempat menjadi dibelakang penari perempuan dengan formasi lifting dan berjalan kedepan. Hal ini dimaknai sebagai persatuan dalam memikul beban dan tanggungjawab yang ditanggung bersama. 


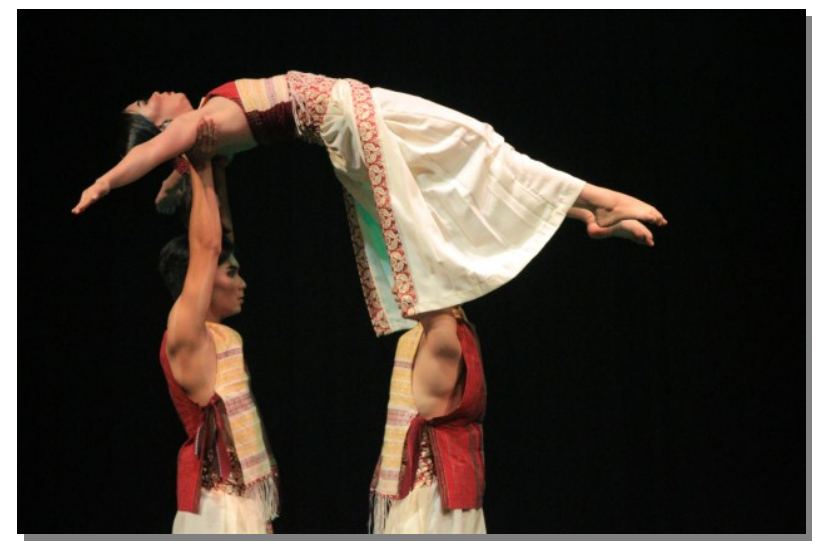

e) Adegan Kelima

Adegan kelima merupakan adegan terakhir dalam karya ini. Adegan ini menyatakan tentang rasa saling memiliki atau ikatan antar ketiga hubungan fungsional. Pada bagian ini iringan musik yang digunakan sangat didominasi oleh instrumen suling yang mendayu-dayu. Sehingga membangun rasa haru akibat ikatan kuat yang dimiliki ketiga kedudukan fungsional tersebut. Adegan kelima ini merupakan adegan klimaks dalam karya "Hahomion Na Tolu". Adegan kelima diawali oleh penari perempuan yang bergerak sendirian di dead center. Lalu muncul salah satu penari laki-laki berjalan dengan menjunjung Tandok di kepala dari side wing belakang kanan penonton lalu mengikuti gerakan penari perempuan. Selanjutnya, penari laki-laki yang berada didalam stage berlari menuju side wing belakang kiri penonton menjemput penari laki-laki lainnya.

Penari laki-laki yang dijemput tersebut lalu mengikuti gerakan penari perempuan dengan menggunakan properti. Selanjutnya kedua penari laki-laki saling berpegangan tangan sambil menjunjung properti Tandok dan mengeliling penari perempuan. Lalu penari peremuan ikut bergabung bersama kedua penari laki-laki dengan berpegangan tangan sambil menjunjung Tandok, serta berjalan melingkar hingga membentuk pola segitiga seperti pola segitiga di bagian awal. Hal ini dimaknai sebagai ungkapan rasa saling memiliki antar tiga kedudukan fungsional,yang mana diantara ketiganya tidak akan membiarkan ataupun meninggalkan satu sama lain, serta berusaha selalu ada diantara ketiganya.

Pada bagian akhir adegan ini, ketiga penari mulai menurunkan properti dan berjalan sambil menumpahkan beras yang ada didalam properti hingga membentuk pola segitiga. Selanjutnya ketiga penari berkumpul membentuk formasi di dalam pola segitia yang dibuat dengan beras, lalu ketiga penari melihat ke atas sembari lampu fade out. Pola segitiga yang dibuat melalui beras dianggap menjadi suatu ikatan yang melingkupi atau mengikat ketiga kedudukan fungsional tersebut. 


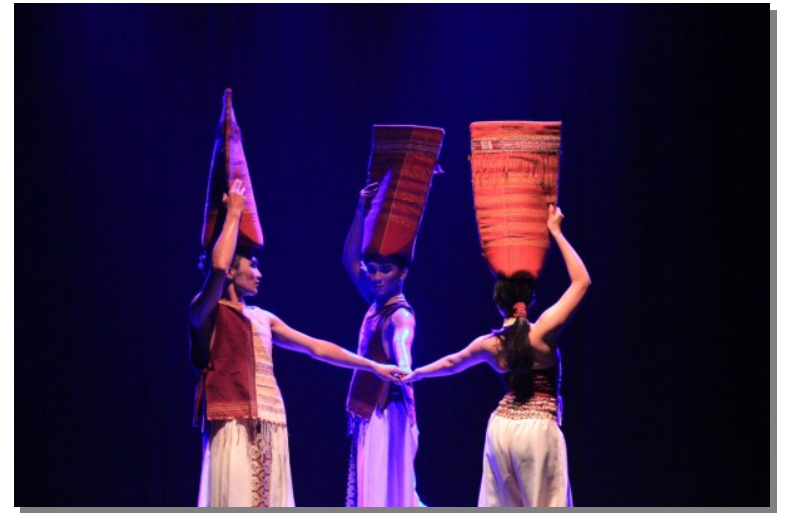

1. Realisasi Musik Tari

$$
\text { Garapan musik tari yang }
$$

menggunakan beberapa macam instrumen musik Barat dan musik Gondang UningUningan Batak seperti, suling Batak, hesek, sarune, hasapi, ogung, tagading, organ, multiple, dan bass. Motif-motif yang digunakan oleh penata musik merupakan eksplorasi dari pengembangan pola-pola musik instrumen tersebut. Karya "Hahomion $\mathrm{Na}$ Tolu" ini juga menggunakan dialog percakapan dengan berbahasa Batak dan syair yang juga dalam bahasa Batak disebut umpasa atau nasehat. Umpasa yang digunakan dalam karya ini yaitu umpasa yang berkaitan dengan pemberkatan dan permohonan, dan berisi tentang berkat yang abadi dari Yang Maha Kuasa.

\section{Realisasi Rias dan Busana}

Elemen seperti rias dan busana sangat berperan dalam menguatkan karakter ataupun raut wajah penari. Dalam realisasinya penata dapat mewujudkan rias busana sesuai dengan konsep. Penari laki-laki dan penari perempuan menggunakan celana yang cukup lebar sehingga memiliki desain tertunda ketika melakukan gerak. Bagian 'atasan' penari dibuat cukup ketat tanpa lengan, sehingga memudahkan penari ketika melakukan gerakan tangan. Untuk penari putra, desain 'atasan' berupa rompi dengan tali pengikat sisi kanan dan kiri. Keselurahan kostum penari menggunakan bahan tradisional Batak yaitu kain Ulos yang memiliki warna merah, hitam, dan putih, warna khas yang selalu digunakan pada setiap kegiatan adat.

\section{Realisasi Properti}

Salah satu cara untuk mewujudkan beban dan tanggung jawab dalam menjunjung adat dan tradisi batak dalam konsep koreografi "Hahomion Na Tolu", penata tari menghadirkan tiga buah properti Tandok. Tandok ialah sebuah wadah untuk meletakkan beras yang dibawa dengan cara diletakan di atas kepala. Properti Tandok ini biasanya digunakan masyarakat Batak untuk menghadiri acara adat dengan membawa Tandok yang berisi beras. Hal ini dimaknai sebagai cara mereka untuk saling peduli dan membantu keberlangsungan kegiatan adat. Beras yang dibawa dimaknai sebagai berkat. Hal ini yang dijadikan pertimbangan dalam 
pemanfaatan Tandok berisi beras sebagai properti tari.

\section{PENUTUP}

Karya "Hahomion Na Tolu" merupakan karya yang terinspirasi dari sebuah objek yaitu Dalihan Natolu (tungku berkaki tiga) sebagai pandangan hidup masyarakat Batak, tentang tiga kedudukan fungsional yang saling berkaitan, berhubungan dan ketergantungan. Karya ini diciptakan dengan tujuan untuk memberikan pengetahuan baru bagi masyarakat yang belum mengetahui keterkaitan antar tiga kedudukan fungsional tersebut. Meskipun telah dipersiapkan dengan baik, tetap saja ada beberapa hal yang menjadi kendala dalam proses penciptaan hingga menuju pementasan karya. Kendala tersebut berkaitan dengan kurang baiknya pendukung dalam mengatur dan membagi waktu, sehingga jadwal yang telah dirancang sejak awal sering mengalami perubahan. Sebuah komitmen tidak selalu mudah dalam pelaksanaannya

Pengolahan jumlah tiga penari dalam karya ini juga menjadi suatu proses pembelajaran bagi penata dalam mengolah koreografi kelompok (trio). Pengkomposisian tiga penari harus banyak mempertimbangkan ruang gerak, bentuk gerak, dan pola lantai. Pola lantai yang bisa diolah dengan jumlah tiga penari sangat sedikit kemungkinannya, tetapi hal ini dapat diatasi dengan cara mencari pola gerak locomotor movement yang variatif agar tidak membosankan, dan mencari bentuk gerak yang unik serta menggunakan gerakan mengangkat (lifting) dengan beragam formasi.

Terlepas dari kendala yang ada, penata merasa cukup puas dengan pengkaryaan "Hahomion Na Tolu" ini. Segala sesuatu yang telah dirancang, dipikirkan, dan dipersiapkan dapat diwujudkan ke dalam suatu karya yang utuh. Harapan ke depannya semoga dengan terciptanya karya ini, banyak orang yang semakin memahami makna yang terdapat dalam Dalihan Natolu. Karya ini diharapkan juga dapat memberikan pembelajaran ataupun inspirasi bagi para penata tari dalam menggarap karya tari dengan jumlah tiga orang penari.

Penata tari menyadari masih banyak hal yang harus dibenahi dan terus diperbaiki, baik dari sisi proses penciptaan karya maupun proses penulisan skripsi. Namun, dibalik itu semua ada hal penting yang dialami yaitu terjadinya proses pendewasaan diri. Sebuah proses penciptaan karya merupakan tahapan pendewasaan diri bagi penata karena dalam berkarya, kita diajarkan untuk menjunjung nilai kejujuran, mampu bersikap arif dalam menyelesaikan persoalan terlebih yang berkaitan dengan pribadi-pribadi dari pendukung karya. Sebuah proses harus dihargai untuk menuju satu titik keberhasilan. 


\section{DAFTAR SUMBER ACUAN}

\section{A. Sumber Tertulis}

Gultom, Dj.Raja Marpodang. 2001. Dalihan Natolu Nilai Budaya Suku Batak.

Yogyakarta: Adicita

Hadi, Y.Sumandiyo. 2003. Aspek-Aspek Dasar Koreografi Kelompok. Yogyakarta: Elkaphi.

2014. Koreografi Bentuk Teknik, Isi. Yogyakarta: Cipta Media.

Haryamawan, RMA. 1988. Dramaturgi. Bandung: Rosda Offset.

Hawkins, Alma. M. 1988. Creating Through Dance, terjemahan Y. Sumandiyo Hadi, 2006, Mencipta Lewat Tari. Yogyakarta: Manthili

Kaplan, David dan Albert A. Manners. 1999. Teori Budaya. Yogyakarta: Pustaka Pelajar.

Koentjaraningrat. 1970. Manusia dan Kebudayaan Indonesia. Djakarta: Djambatan.

Kussudiardja, Bagong. 2000. Dari Klasik Hingga Kontemporer. Yogyakarta: Padepokan Press, Yayasan Bagong Kussudiardja

Martono, Hendro. 2010. Mengenal Tata Cahaya Seni Pertunjukan. Yogyakarta: Cipta Media

2012. Ruang Pertunjukan dan Berkesenian. Yogyakarta: Cipta Media

Murgiyanto, Sal. 1983. Koreografi, Jakarta: Departemen Pendidikan dan Kebudayaan.
1986.

"Dasar-Dasar

Koreografi Tari," dalam

Pengetahuan Elementer Tari dan

Beberapa Masalah Tari,

penyunting Fx. Sutopo

Cokrohamijoyo dkk, Jakarta,

Direktorat Kesenian Proyek

Pengembangan Kesenian Jakarta

Departemen Pendidikan dan

Kebudayaan.

Peursen, C. A. Van, 1980. De Opbouu' van de Wetenschap een inleiding in de wetenschapsleer terjemahan J. Drost (1985), Susunan Ilmu Pengetahuan Sebuah Pengantar Filsafat Ilmu, Jakarta: PT Gramedia.

Purba, Krismus. 2002. Opera Batak Tilhang Serindo Pengikat Budaya Masyarakat Batak di Jakarta. Yogyakarta: Kalika.

Siahaan, Binsar Muller. 2009. Parrambuan Adat Batak Dalihan Natolu. Medan: Trabulan

Sihombing, T.M. 1989. Jambar Hata Dongan Tu Ulaon Adat. Medan: Tulus Jaya.

Sinaga, Richard. 1999. Meninggal Adat Dalihan Na Tolu. Jakarta: Dian Utama.

Smith, Jacqueline.1976. Dance Composition: A Practical Guide For Teachers. London: Lepus Book, terj.Ben Suharto, S.S.T.1985. Komposisi Tari Sebuah Petunjuk Praktis Bagi Guru. Yogyakarta: Ikalasti.

Soedarsono, R. M. 2002. Seni Pertunjukan Indonesia di Era Globalisasi. Yogyakarta. Gadjah Mada University Press.

Sumardjo, Jakob. 2010. Estetika Paradoks. Bandung: Sunan Ambu STSI Press 


\section{JOGED}

ISSN: $1858-3989$

Sumaryono, Endo Suanda. 2006. Tari

Tontonan. Jakarta: Lembaga

Pendidikan Seni Nusantara
Rines Onyxi Tampubolon (HAHOMION NA TOLU) 